\title{
Pengembangan perangkat pembelajaran matematika berbasis pendekatan saintifik pada pokok bahasan teorema pythagoras untuk siswa SMP kelas VIII
}

\author{
Mohammad Emsa Arifin, Indriati Nurul Hidayah* \\ Universitas Negeri Malang, Jl. Semarang No. 5 Malang, Jawa Timur, Indonesia \\ *Penulis korespondensi, Surel: indriati.nurul.fmipa@um.ac.id
}

Paper received: 01-12-2021; revised: 15-12-2021; accepted: 31-12-2021

\begin{abstract}
Abstrak
Penyelenggaraan pembelajaran matematika yang mampu mengaktifkan siswa tidak lepas dari peran guru dalam mengembangkan perangkat pembelajaran yang sesuai dengan tujuan pembelajaran. Tujuan dari penelitian ini adalah untuk menghasilkan perangkat pembelajaran berupa RPP dan LKS materiteorema Pythagoras untuk siswa SMP kelas VIII yang valid dan praktis. Pengembangan perangkat pembelajaran ini berdasarkan model pengembangan Plomp namun hanya 4 tahap yaitu: (1) tahap investigasi awal, (2) tahap desain, (3) tahap realisasi, dan (4) tahap tes, evaluasi, dan revisi. Berdasarkan analisis pengembangan diperoleh hasil bahwa perangkat pembelajaran yang dikembangkan dinyatakan valid dan praktis.
\end{abstract}

Kata kunci: perangkat pembelajaran; pendekatan saintifik; teorema Pythagoras

\section{Pendahuluan}

Suatu pembelajaran matematika hendaknya mengajak peserta didik untuk mempelajari konsep-konsep matematika dari hal yang konkret menuju ke hal yang abstrak agar para siswa dapat memahami konsep-konsep yang dipelajari dengan lebih mudah. Wena (2011) menyatakan bahwa pembelajaran adalah proses komunikasi guru dengan siswa dan sumber belajar pada suatu lingkungan belajar.

Berdasarkan wawancara penulis dengan beberapa siswa SMP kelas VIII pada akhir bulan November 2014 pembelajaran matematika yang dilaksanakan masih bersifat konvensional yaitu guru masih menjadi pusat informasi dan peserta didik hanya menjadi penerima informasi. Pembelajaran konsep-konsep matematika masih sering dilakukan dengan metode ceramah sehingga kebanyakan peserta merasa bosan dengan pembelajaran konfensional ini. Hal ini berdampak pada kurangnya kemampuan peserta didik dalam memahami konsep-konsep matematika yang sedang dipelajari. Ariani dan Harianto (2010) mengungkapkan bahwa sekitar $80 \%$ siswa mengomentari bahwa metode ceramah yang cenderung "top down" dan sentralistik dari para guru di kelas cenderung sangat membosankan sekalipun sudah bertendensi "student oriented" atau "student center" terkesan formal dan sangat minim prosentase daya serap materi dan atensi peserta didik.

Selain itu, penulis juga melakukan wawancara tentang pemahaman materi teorema Pythagoras. Dari hasil wawancara diperoleh informasi bahwa kebanyakan siswa masih belum paham tentang teorema Pythagoras. Mereka hanya hafal teorema tersebut tanpa memahami syarat agar teorema tersebut dapat digunakan dan mengetahui penggunaan teroema tersebut dalam menyelesaikan permasalahan matematika terkait dengan teorema Pythagoras. Selain itu masih banyak siswa yang belum mampu mengaplikasikan penggunaan teorema Pythagoras pada beberapa permasalahan matematika yang nonrutin. 
Masalah terkait ketidakmampuan siswa dalam memahami konsep yang mereka dapatkan untuk menyelesaikan soal teorema Pythagoras ini memerlukan pendekatan pembelajaran yang dapat meningkatkan ketrampilan siswa dalam memahami konsep untuk menyelesaikan masalah terkait konsep yang dipelajari. Salah satu pendekatan yang bisa dijadikan solusi dari masalah tersebut adalah pendekatan saintifik, karena pendekatan saintifik merupakan suatu cara atau mekanisme pembelajaran untuk memfasilitasi siswa agar mendapatkan pengetahuan dan ketrampilan dengan prosedur yang didasarkan pada metode ilmiah (Kemendikbud, 2013).

Menurut Peraturan Menteri Pendidikan dan Kebudayaan Republik Indonesia Nomor 81A tahun 2013, pendekatan saintifik terdiri dari 5 pengalaman belajar pokok, yaitu : (1) mengamati, siswa melakukan kegiatan membaca, mendengar, menyimak, melihat (tanpa atau dengan alat); (2) menanya, siswa mengajukan pertanyaan tentang informasi yang dipahami atau informi tambahan tentang apa yang diamati; (3) mengumpulkan informasi; (4) mengolah informasi, siswa mengasosiasikan hasil pengamatan dan informasi yang terkumpul menjadi kesimpulan; dan (5) mengomunikasikan, siswa menyampaikan hasil pengamatan, kesimpulan berdasarkan hasil analisis secara lisan, tertulis, atau media lainnya

Namun, untuk menyelesaikan masalah di atas tidak hanya dengan mengubah pendekatan pembelajaran yang digunakan. Guru hendaknya menyusun suatu perangkat pembelajaran sebelum kegiatan pembelajaran dilakukan. Perangkat pembelajaran tersebut harus sesuai dengan pendekatan yang digunakan. Menurut Trianto (2007:68), perangkat pembelajaran merupakan segala sesuatu yang digunakan oleh guru dalam mengelola kegiatan pembelajaran dan terdiri atas silabus, Rencana Pelaksanaan Pembelajaran (RPP), Lembar Kegiatan Siswa (LKS), buku siswa, instrumen evaluasi, dan media pembelajaran. Perangkat pembelajaran yang baik tentu membantu guru untuk dapat menyelenggarakan pembelajaran yang berkualitas bagi siswa.

Berdasarkan uraian di atas, akan dikembangkan perangkat pembelajaran matematika berupa RPP dan LKS dengan pendekatan saintifik pada pokok bahasan teorema Pythagoras. RPP dengan pendekatan saintifik adalah bentuk perencanaan yang menggambarkan kegiatan-kegiatan yang akan dilakukan dalam suatu kegiatan pembelajaran yang mana kegiatan-kegiatan tersebut memuat lima kegiatan pokok dalam pendekatan saintifik. Sedangkan LKS dengan pendekatan saintifik merupakan bahan ajar berisi tugas yang harus diselesaikan oleh siswa dengan mengikuti langkah-langkah atau petunjuk yang terdiri dari lima kegiatan pokok dalam pendekatan saintifik agar siswa dapat belajar secara terarah untuk mencapai KD. Sehingga perangkat pembelajaran yang akan dikembangkan dapat membantu siswa dalam menyelesaikan masalah pada pokok bahasan teorema Pythagoras.

\section{Metode}

Penelitian ini merupakan penelitian pengembangan, yaitu pengembangan perangkat pembelajaran dengan pendekatan saintifik pada pokok bahasan teorema Pythagoras yang mengacu pada model yang dikemukakan oleh Plomp (Hobri, 2010). Model pengembangan yang dikemukakan oleh Plomp terdiri atas 5 tahap, yaitu 1) tahap investigasi awal, 2) tahap desain, 3) tahap realisasi, 4) tahap evaluasi, tes, dan revisi, dan 5) tahap implementasi. Namun, penelitian ini hanya dilakukan sampai pada tahap tes, evaluasi, dan revisi dikarenakan keterbatasan biaya dan waktu pelaksanaan. 
Pada penelitian ini, dilakukan 2 uji untuk mengetahui kualitas produk yang dikembangkan, yaitu uji kevalidan dan uji kepraktisan. Uji kevalidan dilakukan untuk melihat apakah produk yang telah dikembangkan sesuai dengan teori pengembangan perangkat pembelajaran dan lima tahapan pokok pada pendekatan saintifik. Uji kepraktisan dilakukan untuk mengetahui keterterapan perangkat pembelajaran yang dihasilkan dalam proses pembelajaran, apakah mudah digunakan dan dipahami atau tidak.

Uji kevalidan menggunakan angket validasi RPP dan LKS yang diisi oleh 1 orang dosen matematika dan 1 orang guru matematika SMP yang telah berpengalaman di bidangnya. Uji kepraktisan dilakukan menggunakan angket respon siswa yang diisi oleh 9 orang siswa kelas VIII sebagai subjek uji coba.

Teknik analisis data hasil uji kevalidan dan kepraktisan yang dilakukan sesuai teknik analisis dalam Hobri (2010), yaitu: 1) melakukan rekapitulasi data penilaian produk ke dalam tabel yang meliputi aspek, indikator, dan nilai untuk masing-masing validator, 2) menentukan rata-rata nilai hasil penilaian dari semua validator untuk setiap indikator, 3) menentukan rerata nilai untuk setiap aspek, dan 4) menentukan persentase kevalidan atau persentase kepraktisan, yaitu nilai rerata total dari rerata nilai untuk semua aspek. Selanjutnya, hasil yang diperoleh akan dibandingkan dengan kriteria kevalidan atau kepraktisan perangkat pembelajaran seperti pada Tabel 1 .

Tabel 1. Kriteria Kevalidan atau Kepraktisan Perangkat Pembelajaran

\begin{tabular}{cll}
\hline Persentase & Kategori & Keterangan \\
\hline $85 \leq P<100$ & Sangat valid/sangat praktis & Tidak perlu revisi \\
$70 \leq P<85$ & Valid/praktis & Tidak perlu revisi \\
$55 \leq P<70$ & Cukup valid/cukup praktis & Revisi sebagian \\
$40 \leq P<55$ & Kurang valid/kurang praktis & Revisi sebagian \\
$0 \leq P<40$ & Tidak valid/tidak praktis & Revisi total \\
\hline
\end{tabular}

\section{Hasil dan Pembahasan}

Hasil dari pengembangan perangkat pembelajaran ini adalah berupa RPP dan LKS dengan pendekatan saintifik pada pokok bahasan teorema Pythagoras. RPP dikembangkan untuk dua pertemuan, masing-masing $2 \times 40$ menit, sedangkan LKS yang dihasilkan terdiri dari LKS 1 tentang menemukan konsep teorema Pythagoras dan LKS 2 tentang penerapan teorema Pythagoras untuk menyelesaikan masalah kehidupan sehari-hari. LKS yang dikembangkan terdiri atas : (1) halaman sampul yang memuat judul LKS, identitas kelompok, kompetensi dasar, indikator pencapaian kompetensi, dan petunjuk belajar; (2) halaman lembar kerja dengan pendekatan saintifik yang terdiri dari lima kegiatan pokok yaitu mengamati, menanya, mengumpulkan informasi, mengolah informasi, dan mengomunikasikan; dan (3) halaman latihan soal.

Data yang diperoleh dari uji kevalidan terdiri dari data hasil uji kevalidan RPP dan hasil uji kevalidan LKS. Analisis data hasil uji kevalidan RPP oleh validator disajikan pada Tabel 2 sebagai berikut. 
Tabel 2 Analisis Data Hasil Uji Kevalidan RPP oleh Validator

\begin{tabular}{|c|c|c|c|c|}
\hline No. & Aspek yang Dinilai & $\begin{array}{l}\text { Persentase } \\
\text { Kevalidan }\end{array}$ & $\begin{array}{l}\text { Kriteria } \\
\text { Kevalidan }\end{array}$ & Keterangan \\
\hline 1. & Kelayakan Isi & $92 \%$ & Sangat Valid & Tidak Revisi \\
\hline 2. & $\begin{array}{l}\text { Kesesuaian dengan pendekatan } \\
\text { saintifik }\end{array}$ & $95 \%$ & Sangat Valid & Tidak Revisi \\
\hline 3. & Kebahasaan dan Kegrafisan & $97 \%$ & Sangat Valid & Tidak Revisi \\
\hline
\end{tabular}

Secara keseluruhan aspek terhadap RPP yang telah dikembangkan, diperoleh peresentase kevalidan sebesar $94 \%$ dan berada pada kriteria kevalidan sangat valid. Dengan demikian, dapat disimpulkan bahwa RPP yang dikembangkan valid dan tidak perlu revisi. Namun, peneliti tetap melakukan revisi berdasarkan saran dan masukan dari validator untuk menyempurnakan RPP yang dikembangkan.

Tabel 3 Analisis Data Hasil Uji Kevalidan LKS oleh Validator

\begin{tabular}{cllll}
\hline No. & Aspek yang Dinilai & $\begin{array}{l}\text { Persentase } \\
\text { Kevalidan }\end{array}$ & $\begin{array}{l}\text { Kriteria } \\
\text { Kevalidan }\end{array}$ & Keterangan \\
\hline 1. & Kelayakan Isi & $94 \%$ & Sangat Valid & Tidak Revisi \\
2. & Kebahasaan & $100 \%$ & Sangat Valid & Tidak Revisi \\
3. & Tampilan & $94 \%$ & Sangat Valid & Tidak Revisi \\
4. & Kesesuaian dengan & $90 \%$ & Sangat Valid & Tidak Revisi \\
& pendekatan scientific & & & \\
\hline
\end{tabular}

Pada Tabel 3 disajikan hasil analisis data dari uji kevalidan LKS yang dikembangkan. Secara keseluruhan, LKS yang telah dikembangkan memperoleh persentase kevalidan 91\% yang berada pada kriteria kevalidan sangat valid. Berdasarkan hasil tersebut dapat disimpulkan bahwa LKS yang telah dikembangkan valid dan tidak perlu dilakukan revisi. Namun, peneliti tetap melakukan revisi berdasarkan saran dan masukan validator untuk menyempurnakan LKS yang dikembangkan.

Selain uji kevalidan, produk yang dikembangkan berupa RPP dan LKS diuji kepraktisannya. Analisis data hasil uji kepraktisan LKS disajikan pada Tabel 4 sebagai berikut.

Tabel 4 Analisis Data Hasil Uji Kepraktisan LKS oleh Siswa Subjek Uji Coba

\begin{tabular}{|c|c|c|c|c|}
\hline No. & Aspek yang Dinilai & $\begin{array}{l}\text { Persentase } \\
\text { Kepraktisan }\end{array}$ & $\begin{array}{l}\text { Kriteria } \\
\text { Kepraktisan }\end{array}$ & Keterangan \\
\hline 1. & $\begin{array}{l}\text { Saya mudah memahami } \\
\text { informasi, petunjuk, dan } \\
\text { pertanyaan dalam Lembar Kerja } \\
\text { Siswa (LKS) }\end{array}$ & $89 \%$ & $\begin{array}{l}\text { Sangat } \\
\text { Praktis }\end{array}$ & Tidak Perlu Revisi \\
\hline 2. & $\begin{array}{l}\text { Saya dapat mengungkapkan ide } \\
\text { dengan bahasa sendiri }\end{array}$ & $86 \%$ & $\begin{array}{l}\text { Sangat } \\
\text { Praktis }\end{array}$ & Tidak Perlu Revisi \\
\hline 3. & $\begin{array}{l}\text { Saya dapat menemukan sendiri } \\
\text { konsep teorema Pythagoras } \\
\text { setelah melakukan kegiatan } \\
\text { dalam Lembar Kerja Siswa (LKS) }\end{array}$ & $83 \%$ & Praktis & Tidak Perlu Revisi \\
\hline 4. & $\begin{array}{l}\text { Saya terlibat aktif dalam } \\
\text { menemukan konsep }\end{array}$ & $72 \%$ & Praktis & Tidak Perlu Revisi \\
\hline
\end{tabular}




\begin{tabular}{|c|c|c|c|c|}
\hline 5. & $\begin{array}{l}\text { Saya terdorong untuk } \\
\text { berinteraksi dan bekerja sama } \\
\text { dalam diskusi kelompok }\end{array}$ & $89 \%$ & $\begin{array}{l}\text { Sangat } \\
\text { Praktis }\end{array}$ & Tidak Perlu Revisi \\
\hline 6. & $\begin{array}{l}\text { Saya mudah memahami kalimat } \\
\text { dan bahasa dalam Lembar } \\
\text { Kegiatan Siswa (LKS) }\end{array}$ & $78 \%$ & Praktis & Tidak Perlu Revisi \\
\hline 9. & $\begin{array}{l}\text { Jenis dan ukuran huruf mudah } \\
\text { dibaca }\end{array}$ & $94 \%$ & $\begin{array}{l}\text { Sangat } \\
\text { Praktis }\end{array}$ & Tidak Perlu Revisi \\
\hline 10. & Tampilan LKS menarik & $89 \%$ & $\begin{array}{l}\text { Sangat } \\
\text { Praktis }\end{array}$ & Tidak Perlu Revisi \\
\hline
\end{tabular}

Secara keseluruhan, persentase kepraktisan LKS yang dikembangkan adalah 85\%. Hal ini menunjukkan bahwa LKS yang dikembangkan berada dalam kriteria kepraktisan sangat praktis sehingga tidak perlu direvisi. Namun demikian, peneliti tetap melakukan revisi terhadap bagian-bagian yang memiliki kekurangan berdasarkan saran dari subjek uji coba, khususnya pada bagian menanya LKS .

\section{Simpulan}

Kelebihan dari perangkat pembelajaran berupa RPP dan LKS yang dikembangkan adalah (1) melalui lima kegiatan mengamati, menanya, mengumpulkan informasi, mengasosiasi, dan mengomunikasikan siswa dapat mengembangkan kreativitas, mengembangkan kemampuan merumuskan pertanyaan untuk berfikir kritis, mengembangkan sikap teliti dan jujur, meningkatkan kemampuan berkomunikasi dan menghargai pendapat orang lain; (2) perangkat pembelajaran dapat meningkatkan keaktifan belajar siswa dalam proses pembelajaran; (3) LKS yang dikembangkan memiliki tampilan yang menarik; dan (4) perangkat pembelajaran mudah dipahami siswa. Sedangkan kekurangan perangkat pembelajaran yang dikembangkan adalah alokasi waktu yang dibutuhkan untuk pengerjaan LKS cenderung lebih dari waktu yang direncanakan terutama pada LKS 1 . Percobaan yang dilakukan cenderung memakan waktu lebih banyak sehingga hanya ada sebagian kelompok yang bisa mempresentasikan hasil kerja mereka.

Berdasarkan hasil penelitian yang telah dilakukan peneliti, maka saran yang direkomendasi, yaitu : (1) Hasil pengembangan berupa perangkat pembelajaran dengan pendekatan saintifik ini diharapkan dapat digunakan sebagai alternatif pembelajaran pokok bahasan teorema Pythagoras untuk siswa SMP kelas VIII; (2) Uji coba perangkat pembelajaran yang dikembangkan terbatas pada kelompok kecil dengan sembilan siswa sebagai subjeknya. Oleh karena itu diharapkan bagi penulis yang lain untuk melakukan uji coba perangkat pembelajaran pada kelompok besar untuk mendapatkan hasil yang lebih meyakinkan; (3) Pokok bahasan pada perangkat pembelajaran yang dikembangkan terbatas pada teorema Pythagoras. Oleh karena itu diharapkan untuk penulis lain dapat mengembangkat perangkat pembelajaran dengan pendekatan saintifik untuk materi yang lain, sehingga dapat menambah alternatif guru dan sumber belajar yang lain; dan (4) bagi penulis lain disarankan agar mengembangkan perangkat pembelajaran dengan pendekatan saintifik pada pokok bahasan teorema Pythagoras yang juga mengukur tingkat keefektifan perangkat pembelajaran dari semua aspek penilaian yaitu, sikap, pengetahuan, dan ketrampilan. 


\section{Daftar Rujukan}

Ariani, N., \& Haryanto, D. (2010). Pembelajaran multimedia di sekolah. Jakarta: Prestasi Pustaka.

Hobri, H. (2010). Metodologi penelitian pengembangan (aplikasi pada penelitian pendidikan matematika). Jember: Pena Salsabila.

Pendidikan, P. M., \& Nomor, K. R. I. (2013). 81A tahun 2013 tentang implementasi kurikulum pedoman umum pembelajaran. Jakarta: Kementrian Pendidikan dan Kebudayaan RI.

Trianto, S. P., \& Pd, M. (2007). Model pembelajaran terpadu dalam teori dan praktek. Jakarta: Prestasi Pustaka.

Wena, Made. (2011). Strategi pembelajaran inovatif kotemporer: suatu tinjauan konseptual operasional. Jakarta: Bumi Aksara. 